\title{
Mikro Ünlülerin Tüketicilerin Satın Alma Niyeti Üzerindeki Etkisini İncelemeye Yönelik Ampirik Bir Çalışma ${ }^{12}$
}

\author{
DOI: $10.26466 /$ opus.583856
}

*

\begin{abstract}
Ebru Tümer Kabadayı* - Alev Koçak Alan ${ }^{* *}$ - Nilșah Cavdar Aksoy ${ }^{* \star *}$ - Salih Can Sidar ${ }^{\star \star * *}$ * Prof. Dr., Gebze Teknik Üniversitesi, İşletme Fakültesi, Gebze / Kocaeli / Türkiye

E-Posta: tumer@gtu.edu.tr

ORCID: $\underline{0000-0002-0673-6866}$

${ }^{*}$ Dr. Öğr. Üyesi, Gebze Teknik Üniversitesi, İşletme Fakültesi, Gebze / Kocaeli / Türkiye

E-Posta: akocak@gtu.edu.tr

ORCID: $0000-0002-1060-1593$

**** Arş. Gör., Gebze Teknik Üniversitesi, İşletme Fakültesi, Gebze / Kocaeli / Türkiye

E-Posta: n.cavdar@gtu.edu.tr

ORCID: 0000-0003-0734-3930

***** Yüksek Lisans Öğrencisi, Gebze Teknik Üniversitesi, İşletme Fak., Gebze / Kocaeli / Türkiye

E-Posta sidar@outlook.com.tr ORCID: $\underline{\text { 0000-0003-1571-0198 }}$

Öz
\end{abstract}

Sosyal medya platformlarının dinamik doğası gereği binlerce kişiye ulaşabilme imkânı sağlaması, bu platformların hem işletmeler için hem de kullanıcılar için vazgeçilemeyecek kadar değerli bir araç haline gelmelerini sağlamıştır. Sosyal medya kullanan kişiler; takipçi kazanma, paylaşım yapma, beğeni ve yorum alma gibi değişkenlerle kendilerine çeore oluşturma, kendilerini geniş kitlelere tanıtma, adların duyurma firsatı bulmuş ve dijital dünyada yeni bir terim olan "Mikro Ünlüler" kavramının doğmasına neden olmuştur. Bu çalışmada, işletmeler için de geleneksel ünlüler gibi cazip hale gelen mikro ünlüler üzerine bir araştırma yürütülmüştür. Çalışmanın amacı, tüm dünyada olduğu gibi Türkiye gibi gelişmekte olan bir ülkede de giderek artan bir öneme sahip olan ve gü̧̈lü bir iletişim kaynă̆ mikro ünlülerin sosyal medyada yaptıkları tanttımların bireylerin satın alma niyetine etkisini incelemektir. Bu doğrultuda sosyal medya kullanan ve mikro ünlü takip eden 390 kişiye anket uygulanmıştır. Sonuçlar yapısal eşitlik modellemesi ile test edilmiştir. Çalışmanın bulgularına göre, mikro ünlülerin çekiciliği ve ürün-ünlü uyumu tüketici tutumunu pozitif şekilde etkilemekte, neticesinde tüketici tutumu elektronik ortamda ağızdan ağıza iletişimi ve nihayetinde satın alma niyetini olumlu şekilde etkilemektedir. Diğer yandan, mikro ünlülerin uzmanlığı ve güvenilirliğinin tüketici tutumu üzerinde herhangi bir etkisine rastlanmamıştır. Bulgular neticesinde, işletmelere ve gelecek çalışmalara öneriler sunulmuş ve araştırma kısıtları aktarılmıştır.

Anahtar Kelimeler: Sosyal medya, mikro ünlüler, ünlü kullanımı, elektronik ağızdan ağgza iletişim, satın alma niyeti

\footnotetext{
${ }^{1}$ Bu çalışma, Salih Can Sidar'ın Yüksek Lisans tezinden üretilmiştir.

${ }^{2}$ Bu çalışmanın genişletilmiş özeti, 02-04 Mayıs 2019 tarihleri arasında Osmaniye'de gerçekleşen 18. Uluslararası İşletmecilik Kongresi'nde sunulmuştur.
} 


\title{
An Empirical Study about the Effect of Micro-Celebrities on Consumers' Purchase Intention
}

\begin{abstract}
The opportunity to reach thousands of people, arising from its dynamic nature, has enabled social media platforms to become an indispensable tool for both businesses and individual users. People who use social media have the opportunity to communicate with others, to introduce themselves to large masses, and promoting their name, to create their own environments with variables such as gaining followers, creating contents, gaining likes and comments. All of these things have brought our lives the term of "Micro-Celebrities". In this study, a research was carried out on these micro celebrities, which have become as attractive as the traditional celebrities. The aim of the study is to examine the effect of the introductions of micro-celebrities, who have become an important source of communication in a developing country like Turkey as well as all over the world, on individuals' purchase intention. To achieve this goal, a questionnaire was conducted with 390 people who are using social media and following micro-celebrities. Survey results were analyzed through structural equation modeling. According to the results, the attractiveness of micro-celebrities and the product matchup between the micro-celebrity and the product they introduce are positively related with consumer attitude, and consequently consumer attitude positively affects electronic word of mouth (eWOM), and finally, eWOM has a positive effect on purchase intention. On the other hand, the expertise of micro-celebrities and trustworthiness of them do not have any effect on consumer attitude. Based on findings, the limitations of the research and suggestions both for future studies and the businesses were given.
\end{abstract}

Keywords: Social media, micro-celebrities, celebrity endorsement, electronic word of mouth, purchase intention 


\section{Giriş}

Teknoloji her sektöre getirdiği gibi pazarlama sektörüne de pek çok yenilik getirmiştir. Dijitalleşmeyle beraber sosyal medya, her geçen gün daha fazla önem kazanmış ve pazarlama dünyasında stratejik bir öneme sahip olmuştur. We Are Social ve Hootsuite şirketleri tarafından her yıl yayınlanan ve sosyal medya alanında en kapsamlı raporlardan biri olarak görülebilecek dijital raporlar serisinin bu yll yayınlanan "Digital 2019 Turkey" verilerine göre; toplam nüfusu 82.44 milyon olan Türkiye'de 52 milyon insan sosyal medya kullanıcısıdır. Türkiye nüfusunun \%63'lük kısmı olan sosyal medya kullanıcılarl, sosyal medyada günde ortalama 2 saat 46 dakika vakit geçirmektedir. Bu bakımdan sosyal medya, ülkemizde oldukça geniş kitlelere hitap etmektedir. Sosyal medyanın gelişimi ile birlikte işletmeler diledikleri zamanda, diledikleri konumdan, diledikleri tüketici grubuna hatta diledikleri tüketiciye ulaşma imkânı elde etmiştir. Böylelikle, geçmişte kullanılan tutundurma çalışmaları sosyal medyanın gelişmesiyle yeni bir soluk kazanmıştır. Ancak sosyal medya sadece işletmeler için değil tüketiciler için de önem arz etmeye başlamıştır. Sosyal medyanın yapısı sayesinde kullanıcılar herhangi bir konudaki görüşlerini özgürce ifade edebilir ve sayısız kişiye ulaştırabilir hale gelmiştir. İstekleri, ihtiyaçları, kararları gibi pek çok konuda görüşlerini sosyal medyada paylaşan bireyler; paylaşımlarının beğenilmesi ve büyük kitlelerce takip edilmesi neticesinde birer "ünlü" haline gelmiştir. Bu bakımdan sosyal medya, tüketiciler ile günümüzde de sık sık birer pazarlama mesajı kaynağı olarak kullanılan ünlüler arasındaki ayrımı ortadan kaldırmış, tüketicilerin de birer ünlü haline gelmelerini sağlamıştır.

Sosyal medyanın sağladığı fikirlerin geniş kitlelere yayılabilmesi avantajı, tüketicilerin sosyal medyadaki yeni rolünün göstergesidir. Yaptıkları paylaşımların yayılması ile belli bir kitle tarafından tanınır hale gelen sosyal medya kullanıcıları için kullanılabilecek en kapsamlı tanımlama "Mikro Ünlü" terimi vasıtasıyla yapılabilir (Khamis, 2017). Mikro-ünlüler, geleneksel ünlülerden farklarının belirtilmesi için kullanılan 'mikro' ön betimlemesi ile anılmaktadırlar.

Bireysel sosyal medya kullanıcıların birer 'ünlü' haline gelmesi, markaların tüketicilerin hayatlarının bir parçası olan sosyal medyayı aktif bir 
şekilde kullanarak diğer tüketicilere ulaşması için yeni bir pazarlama yaklaşımını beraberinde getirmiştir. Zaman içerisinde popülerliklerini artıran mikro ünlülerin sosyal medyada daha çok ün kazanmaları onları markaların gözünde yeni bir tutundurma aracı olarak konumlandırmaktadır. Pazarlama ve tüketici davranışları perspektifiyle mikro ünlüler üzerine yapılan çalışmalar sınırlı sayıdadır (Chung ve Cho, 2017; Djafarova ve Rushworth, 2017; Lim vd., 2017; Hwang ve Zhang, 2018; Djafarova ve Trofimenko, 2019) ve bu çalışmaların çoğu ampirik kanıtlar sunmamaktadır. $\mathrm{Bu}$ çalışmada da mikro ünlülerin tüketicileri ne derecede etkilediklerine yönelik bir araştırma yürütülmektedir. Çalışmanın amacı, sosyal medya ile insanların hayatlarına giren ve tüm dünyada önemli bir iletişim kaynağı haline gelen mikro ünlülerin, gelişmekte olan bir ülkede de giderek artan bir öneme sahip olmasından hareketle, yaptıkları tanıtımların bireylerin satın alma niyeti üzerindeki etkisini incelemektir. Bu bağlamda çalışma, mikro ünlülerin tüketicileri etkileyebilme ve Türkiye'de tüketimi şekillendirebilme gücünün ne olduğu, işletmelere ne şekilde yardımcı olabileceği ve günümüzde geleneksel ünlüler gibi birer pazarlama aracı olarak kullanılıp kullanamayacağı konularına odaklanmaktadır.

\section{Teorik geçmiş}

Pazarlama iletişiminde tüketicilerle iletişim kurulabilmesi ve bu iletişimin başarıya ulaşması için en önemli etken verilmek istenen mesajın kaynağ1dır (Chung ve Cho, 2017). Tüketicilere ulaştırılan mesajların dayanak noktası olan kaynak, mesajın içeriğinden ve tüketiciye ulaştırılma şeklinden çok daha önemli bir özelliğe sahiptir (Jin ve Phua, 2014). İletilmek istenen mesaj ne kadar özenle hazırlanmış olursa olsun; mesajı tüketiciye gösteren, tüketici ile teması sağlayan kaynağın kalitesi daha büyük öneme sahiptir (Um, 2018). Tüketiciler pazarlamacılar tarafından oluşturulan mesajlara maruz kalmadan önce o mesajın kaynağı ile kontak kuracaklardır ve tüketicinin ilk ikna olma aşaması, kaynak ile temas kurduğu ilk anda başlayacaktır (Audi ve Ghazzawi, 2015). Pazarlama çalışmalarında tüketici ile iletişim kurma stratejilerinden biri olan ünlü kullanımı çoğu zaman marka ve kurumsal imajı desteklemek için kullanılmaktadır (Gong ve Li, 2017). İşletmeler markalarını ve kurumsal kişiliklerini güvenilir, çekici ve 
tüketiciye yakın göstermek için yıllardır ünlü kişiler ile beraber çalışmaktadırlar (Erdoğan, 1999).

\section{Kaynak inanılırlı̆̆ı modeli}

Pazarlama faaliyetlerinde ünlü kişilerin kullanılması, araştırmacıların yıllar boyunca incelediği bir konu olmuştur. Bu araştırmacılardan bazıları ünlü kişilerin markalar tarafından nasıl seçilmesi ve kullanılması gerektiği ile ilgili çeşitli modeller ve teoriler geliştirmiştir. $\mathrm{Bu}$ araştırmada geçmişte geliştirilmiş olan Hovland vd. (1953), McGuire (1985), Ohanian'a (1990, 1991) ait model ve teoriler incelenmiştir.

Kaynak inanılırlığı, bir kaynaktan gelen mesajın alıcısı üzerindeki etkililik derecesini ifade etmektedir (Hovland vd., 1953; McGuire, 1958; Ohanian, 1990; Ohanian, 1991). Bu etki, bilgi edinme ve kabul görme bakımından değerlendirilmektedir. Ohanian (1990) bir kaynağın inanılırlığını değerlendirirken Hovland ve arkadaşlarının 'Kaynak İnanılırlığı Modeli' (1953) ile McGuire' nin ‘Kaynak Çekiciliği Modeli'ni (1985) dikkate almıştır. Teorik dayanak olarak bu iki modeli kullanan yazar; kaynağın güvenilirliği, uzmanlığı ve çekiciliği boyutlarını kaynak inanılırlığının bir göstergesi olarak değerlendirmekte ve kaynak inanılırlığını bu üç temel kavram çerçevesinde açılamaktadır. Hovland ve arkadaşları (1953), bir kaynağın inanılır olmasını güvenilirlik ve alanında uzman olma ile ilişkilendirmektedir. McGuire (1985) ise, kaynak çekiciliğine odaklanmıştır ve aşinalık, beğenilebilirlik, benzerlik ve cazibe faktörlerinin çekiciliğin oluşumunda etkili olduğunu savunmuştur.

Kaynak inanılırlığı; mesaj kaynağının doğru bilgi üretme kabiliyeti, algisı ve motivasyonu oluşturması anlamına gelmektedir (Boerman vd., 2017). Kaynak inanılırlığı modeli aynı zamanda tüketicilerin bilgi kaynağının güvenilirliğine, uzmanlığına, çekiciliğine inanarak kaynağı yetkin ve güvenilir olarak algılayıp algılamayacağını açıklamaktadır (Wang vd., 2017). Bu açıklamadan yola çıkılarak kaynak inanılırlığı modeli tüketicilerin, markalar tarafından verilen mesajların doğruluğunu kabullenmelerini sağlayan olumlu özelliklerin bütününü ifade etmektedir. Tüketiciler, sevdikleri ünlülerin pazarlama kampanyalarına maruz kaldıklarında duygu ve düşüncelerinde değişimler görülebilmektedir (McCormick, 2016). Ünlü kullanımlarının sonucu olarak tüketicilerde; içselleştirmeler, 
para-sosyal duygular, kendini açıklama, ve sosyal çevrelerinde ağızdan ağıza iletişime neden olacak çıktılar meydana gelmektedir (Ding ve Qiu, 2017).

\section{Ürün-ünlü uyumu}

Ünlü kullanımı etkilerini belirlemede bir diğer önemli faktör “Ürün-Ünlü Uyumu" modelidir. Ürün-ünlü uyumu modeli, bir ünlünün inanılır olarak kabul edilebilmesi için diğer inanılırlık bileşenleri kadar önem taşımaktadır (Kamins, 1990). Ürün-ünlü uyumu modelinde, ünlü ve ürün arasındaki eşleşme, marka ile ünlü imajı arasındaki algılanan uyum derecesine bağlıdır (Forkan, 1980).

Ürün-ünlü uyumu modeli üzerine yapılan araştırmalar, ünlülerin taş1dığı mesajlar, tanıttıkları ürünlerle uyumlu olduğunda ünlülerin daha etkili olduğunu göstermiştir (Kahle ve Homer, 1985; Kamins, 1990; Kamins ve Gupta, 1994; Till ve Busler, 1998, 2000). İlk çalışmalar, fiziksel çekicilik alanındaki eşleşme etkilerini incelemiş ve çekici ünlülerin, çekiciliği ön planda olan ürünlerde çekici olmayan ünlülerden daha etkili olduğunu öne sürmüştür (Kahle ve Homer, 1985). Bir ünlünün çekiciliği veya uzmanlığı önemli bir eşleştirme faktörü olarak işlev görürken, Kamins ve Gupta (1994) ünlü ile ürün arasındaki genel uyumluluğun tüketici alg1sina daha fazla etkide bulunduğunu belirtmiştir. Ürün ve ünlünün uyumlu olması ve mesajın bu bağlamda tasarlanması, olumlu tutumlar oluşturacaktır; çünkü bireyler ürünün bir ünlü tarafından kullanımını bir kanıt olarak görmektedirler (Hassan ve Jamil, 2014). Ek olarak, eğer birey ürün ile ünlüyü uyumlu bulmazsa, ürünü satın almak onun için finansal bir risk taşıyacaktır (Jagre vd., 2001).

Ürün ile ünlü uyumu çok önemlidir çünkü insanlar ürünü kaynak çerçevesinde tanımlamayı arzu eder (Kamins ve Gupta, 1994). Eğer tüketici ünlüyü kendi sunduğu ürünle uyumlu bulmazsa, kendisi için de satın almayı düşünmeyecektir. İşletmeler tarafından tanıtılacak ürün için ünlü seçilirken bu değişkenler göz önünde bulundurulmalıdır. Eğer tanıtmak istediğiniz ürün ucuz fiyatlı ve ikamesi kolay bir ürünse, bu ürünü tanitmak için dünyaca ünlü bir yıldız ile çalışmanız gerekmemektedir (Kim ve $\mathrm{Na}$, 2007). Çünkü aksi halde, insanların gözünde o ürünün kendi standartlarına göre pahalı olduğu algısı uyanabilir (Biswas vd., 2006). Başka bir 
örnek olarak eğer spor ürünleri için hiçbir sportif başarısı olmayan ya da spor ile ilgilenmeyen bir ünlü seçimi yapılırsa, bu kez tüketici gözünde o markanın spor kalitesi zedelenebilir (Lee ve Thorson, 2008).

Kaynak İnanılırlı̆̆ Modeli (Hovland vd., 1953; Ohanian, 1990; Ohanian, 1991) ve Ürün-Ünlü Uyumu Modeli (Forkan, 1980) bireyleri satın alma davranışına teşvik etmek için doğru bir kaynak seçiminin yapılması gerekliliğine teorik destek sunar. Doğru bir kaynak seçimiyle, oluşturulan etkili mesajlar tüketici davranışlarını şekillendirebilmeyi mümkün kılacaktır. Bu bağlamda satın alma niyetinin oluşumunda, kaynağa ilişkin karakteristik özellikleri simgeleyen kaynak çekiciliği, kaynak uzmanlığı ve kaynak güvenilirliği ile seçilen kaynağın mesajı iletilen ürün ile uyumunu temsil eden ürün-ünlü uyumu kapsamında ortaya çıkabilecek olumlu tutum ve neticesinde elektronik ağızdan ağıza iletişim; çalışmanın odak noktalarını temsil eder. Bu kapsamda oluşturulan araştırma modeli Şekil 1 'de sunulmuştur.

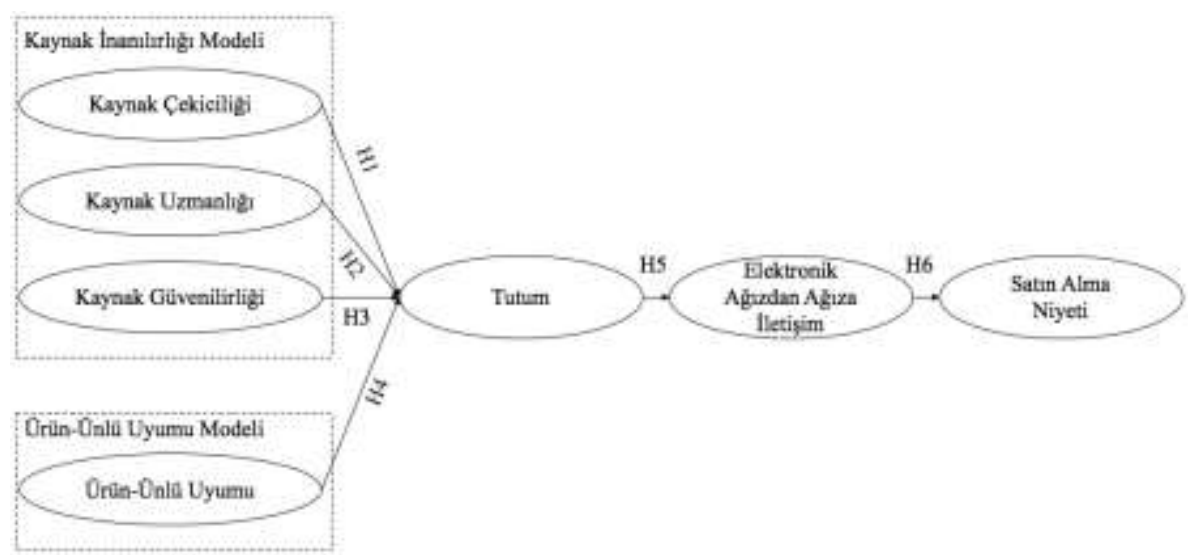

Şekil 1. Araştırma modeli

\section{Hipotez geliştirme}

İnsanlar sosyal medya platformlarını kullanarak geniş kitlelere hitap edebilmektedir (Marwick, 2015). Bu da insanların yeteneklerini ve becerilerini başkalarına tanıtmalarına fırsat sağlamaktadır. İnsanların çevrimiçi araçların sağladığı koşulları kendilerini tanıtmak ve ünlerini yaymak için kul- 
lanmaları, "mikro ünlü"lerin oluşumunu sağlamıştır. Mikro ünlüler sosyal medya platformları ile adlarını geniş kitlelere duyuran kişilerdir (Khamis, 2017). Mikro ünlüler geleneksel ünlüler ile karşılaştırıldığında sosyal ağ siteleri ile ünlü olan bireylerdir (Jin ve Phua, 2014). Bu ünlüler; video, blog ve sosyal ağ sitelerini kullanarak web ortamı üzerindeki popülerliklerini artırmaktadır.

Fenomen olarak da adlandırılabilen bu ünlülerin takipçileri ile ilişkisi, geleneksel medyadaki ünlü-hayran ilişkisinden daha 'gerçekçi' algılanarak gelişmeye devam etmiştir (Khamis, 2017). Sosyal medya aracılığı ile kendilerini geniş kitlelere tanıtan bu kişiler de ünlüler dünyasında kendilerine yer bulmuştur (Jin ve Phua, 2014). Mikro ünlülerin kendilerini ilk olarak sosyal medya ortamlarımda tanıtması ile başlayan süreç; diğer medya araçlarında da genişçe yer bulmaları şeklinde devam etmiştir. Böylelikle, insanlar tarafından tanınır hale gelerek pazarlama çalışmaları için de birer "ünlü kaynak" olarak algılanmaya başlanmışlardır.

\section{Kaynak çekiciliğinin tüketici tutumuna etkisi}

Sosyal medya platformlarında aktif bir şekilde yer alan ve ürettikleri içeriklerle ünlenen bireylerin sahip olduğu popülerlik seviyesi, birer kaynak olarak güvenilir bulunabilecekleri ile ilişkilendirilmiştir (Jin ve Phua, 2014). Takipçi sayısı (Utz, 2010), beğeni ve yorum sayısı (Chung ve Cho, 2017) gibi numerik verilerle gözlemlenebilen popülerlik derecesi, bu bireylerin işletmeler tarafından fark edilmelerine ve birer kaynak olarak kullanılmalarına zemin hazırlamıştır (Um, 2016). Buradaki temel yaklaşım, mikro ünlülerin herhangi bir ürünle ilgili olmayan ve kendilerini paylaştıkları içeriklerin de yüksek beğeni ve yorum almasının onların çekiciliğine işaret ettiği şeklindedir (Jin ve Phua, 2014). Lim ve arkadaşlarının (2017) mikro ünlüler üzerine yaptıkları araştırma sonucu, kaynak çekiciliği ile tüketici tutumu arasında pozitif bir ilişki olduğunu göstermektedir. Buradan hareketle, çekici bir mikro ünlünün tüketicilerin tutumlarını pozitif bir şekilde etkileyebileceğine inanılmaktadır:

- H1: Mikro ünlünün çekiciliği, tüketici tutumu üzerinde pozitif etkiye sahiptir. 


\section{Kaynak uzmanlığının tüketici tutumuna etkisi}

Bir kaynağın uzman olarak algılanması, etkin bir mesaj oluşturulması ve iletilmesinde önemli rol oynar. Till ve Busler (2000) yaptıkları çalışma sonucunda, uzmanlığın bireylerin tutumu üzerinde olumlu bir etkisi olduğunu gözlemlemiştir. Metzger vd., (2003); uzman olarak algılanan bir ünlünün kullanıldığı iletişimde, tüketicilerin maruz kaldıkları reklam mesajlarını daha kolay kabul ettiklerini savunur. Kaynak uzmanlığı, kaynağın inandırıclığına dair diğer önemli faktörlerin etkisi olmadığı durumlarda dahi kritik bir öneme sahip olabilmektedir. Ohanian (1990) bir kaynağın inanılırlığını ölçmek için yaptığı çalışmasında, ünlülerin inanılırlığını simgeleyen boyutlardan yalnızca kaynak uzmanlığının satın alma niyeti üzerinde etkili olduğu sonucuna varmıştır. Uzman olarak görülen kaynaklar, daha ikna edici olma eğilimindedir ve tüketici satın alma niyetini yönlendirebilecek güçtedir (Ohanian 1991). Brison ve arkadaşları (2016) ise, uzman ve tecrübeli sporcuların Twitter üzerinden yayınladıkları mesajların tüketicilerin tutumları üzerindeki etkisini araştırdıkları çalışmalarında, uzman sporcuların tüketicilerin davranışlarına etki edebileceğini keşfetmişlerdir. Buradan hareketle aşağıdaki etkinin varlığı tahmin edilmektedir:

- H2: Mikro ünlünün uzmanlığ1, tüketici tutumu üzerinde pozitif etkiye sahiptir.

\section{Kaynak güvenilirliğinin tüketici tutumuna etkisi}

Güvenilir bir kaynağın kullanıldığı iletişim çalışmalarının daha ikna edici olduğu savunulur (Kamen vd., 1975; Till ve Busler, 1998). Örneğin Miller ve Baseheart (1969) yaptıkları çalışmada, kaynağın güvenilirliği ile iletişimdeki ikna oranı arasındaki pozitif ilişkiyi gözlemlemiştir. Bu çalışmada iki farklı türde kaynağa örnek olacak ünlü isim kullanılmıştır, bunlar güvenilir bir kaynak ve güvenilir olmayan bir kaynak şeklindedir. Çalışma sonunda, güvenilir kaynaktan çıkan mesajların alıcılar üzerinde daha etkili olduğu ve alıcılar tarafından daha kolay kabul edildiği görülmüştür. Bir kaynağın güvenilirliğinin aynı zamanda, tutum değişimine olumlu şekilde etki ettiği savunulmaktadır (McGinnies ve Ward, 1980). Güvenilir 
bir kaynağın; tüketicilerin algısını (Goldsmith vd., 2000), inançlarını, görüşlerini, tutumlarını ve davranışlarını (Wang vd., 2017) olumlu yönde etkileyebileceği görüşlerinden hareketle, aşağıdaki hipotez sunulmuştur:

- H3: Mikro ünlünün güvenilirliği, tüketici tutumu üzerinde pozitif etkiye sahiptir.

\section{Ürün-ünlü uyumunun tüketici tutumuna etkisi}

Bir ünlü ve marka arasında iyi bir uyum söz konusu olduğunda; tüketicilerin o ürün, ünlü ve marka hakkında daha olumlu değerlendirmeler yaptığ1 savunulmaktadır (Kamins, 1990). Belirli bir ünlü, kendi alanına ait bir ürün ile eşleştirildiğinde tüketicilerin gözünde güçlü bir imaj çizmektedir (Kamins ve Gupta, 1994; Biswas ve Biswas, 2006; Wright, 2016). Örnek olarak Brison ve arkadaşları (2016); alanında yeni, ünü duyulmamış bir spor markasını, Twitter üzerinden yayınlanan mesajlarla tanıtmak için iki farklı sporcuya ait hesap seçmiştir. Hesaplardan biri kurgusal, gerçek olmayan biri adına oluşturulurken diğer hesap ise kaynak inanılırlık modeline ait özelliklere (güvenilirlik, çekicilik, uzmanlık) sahip profesyonel bir futbolcu olan Van Persie adına oluşturulmuştur. Çalışma tamamlandığında ulaşılan sonuç Van Persie adına açlan hesaptan yayınlanan reklam mesajlarının, kurgusal olarak hazırlanmış diğer hesaba göre daha fazla beğeni, olumlu yorum, geri bildirim aldığını ve mesajın diğer hesaplarla paylaşıldığını göstermiştir. Tüketici davranışların alanında yürütülmüş olan ürün-ünlü uyumunun tüketici tutumuna etkisi üzerine yapılan çalışmalardan hareketle (Jin ve Phua, 2014; Rifon et. al., 2016), marka ve ürünlerle aralarındaki uyumun da tüketicilerin tutumu üzerinde pozitif etkili olacağına inanılmaktadır:

- H4: Ürün-ünlü uyumu, tüketici tutumu üzerinde pozitif etkiye sahiptir.

\section{Tüketici tutumunun elektronik ortamda ağızdan ă̆ıza iletişime etkisi}

İşletmeler, başarılı bir pazarlama kampanyası geliştirmek için önemli bir gösterge olarak tüketicilerin niyetlerine ve tutumlarına odaklanmaktadır (Wang vd., 2017). Tutum ve satın alma niyeti, tüketici davranışları çalışmalarında ilişkili kavramlar olarak ele alınmaktadır. Örneğin Arli (2017), 
belirli bir ürüne ya da ünlüye yönelik olumlu tutumun tüketicilerin satın alma niyetine yol açabileceğini ileri sürmüştür. Benzer şekilde, sosyal medyada ünlenmiş bireyler tarafından onaylanan bir ürüne yönelik olumlu bir tutum, satın alma niyetinin daha yüksek olmasını sağlayacaktır (Lim vd., 2017). Ancak burada, elektronik ağızdan ağıza iletişimin etkisi göz ardı edilmemelidir. Sosyal medya, mikro ünlülerin önemli bir kaynak olarak algılandığı ve kullanıldığı bir platformdur ve bu platform, ister bireysel tüketici ister işletme olsun tüm kullanıcılar arasında güçlü bir etkileşim yaratmaktadır. Bu etkileşim sayesinde, tüketicilerin aktif bir şekilde rol aldığ 1 bir iletişim ortamı doğmuştur ve bireyler, şirketin kendisinden bilgi almak yerine kendi sosyal ağlarından bilgi alır hale gelmiştir (Harrison, 2001). Günümüzde bu türden bir iletişim, sıklıkla sosyal medya üzerinden yapılmaktadır. Bu tür platformlarda aktif bir şekilde var olan mikro ünlülere karşı tüketicilerin pozitif tutumunun da elektronik ortamdaki bu iletişim ortamını pozitif şekilde etkileyeceğine inanılmaktadır. Buradan hareketle, aşağıdaki önerme sunulmaktadır:

- H5: Tüketici tutumu, elektronik ortamda ağızdan ağıza iletişim üzerinde pozitif etkiye sahiptir.

\section{Elektronik ortamda ağızdan ağıza iletişimin satın alma üzerine etkisi}

Elektronik ortamda ağızdan ağıza iletişim etkili bir pazarlama aracı olarak kabul edilmektedir. Tüketiciler günümüzde, herhangi bir ürünü veya hizmeti satın almadan önce şüphelerini ortadan kaldırmak için diğer müşterilerin deneyimlerine başvururlar (Pitta ve Fowler, 2005) ve bu tür bir iletişimin tüketicilerin satın alma niyetleri üzerindeki etkisi bilinmektedir (Chan ve Ngai, 2011). Sosyal medya kapsamı incelendiğinde, içerisinde sık sık marka diyalogları yer aldığından eWOM'un tüketicilerin satın alma niyetleri üzerinde etkili olduğu gözlemlenmiştir (Erkan ve Evans, 2016). Mikro ünlülerin açığa çıkaracağı etkileşim neticesinde satın alma niyetininde de pozitif bir değişim olacağı inancıyla, aşağıdaki hipotez geliştirilmiştir:

- H6: Elektronik ortamda ağızdan ağıza iletişim, satın alma niyeti üzerinde pozitif etkiye sahiptir. 


\section{Araştırma metodolojisi}

Mikro ünlülerin tüketicilerin satın alma niyeti üzerindeki etkisi ölçmek için bu çalışmada anket yöntemi kullanılmıştır. Anket toplama işlemi için çevrimiçi (online) anket metodu seçilmiştir ve oluşturulan online anketler sosyal ağlar ve mail yolu ile dağıtılmıştır. Anket üç bölümden oluşmaktadır. İlk bölümde demografik sorular yer alırken; ikinci bölüm mikro ünlülerin çekicilik, güvenilirlik, uzmanlıklarına yönelik ifadeler ve tüketici tutumunu ölçen ifadelerden; üçüncü bölümde ise, mikro ünlülerin paylaşım yaptıkları ürünler ile aralarındaki uyumu, takipçiler arasındaki elektronik ortam da ağızdan ağıza iletişimi ve satın alma niyetini ölçen ifadelerden oluşmaktadır.

Ankette kaynak çekiciliğini, uzmanlığını ve güvenilirliğini ölçmek için Wang ve arkadaşlarının (2017); ürün-ünlü uyumunu ölçmek için Choi ve Rifon'un (2012); eWOM için Boerman ve arkadaşlarının (2017); tüketici tutumu için Kim ve Chung (2011) ve Tang ve arkadaşlarının (2007); satın alma niyeti için Kim ve arkadaşlarının (2015) çalışmalarından faydalanılmıştır. Çalışmada, 5’li Likert Ölçeği kullanılmıştır.

Araştırmanın ana kitlesi; İstanbul ve Kocaeli'de yaşayan, 18 yaş üstü, sosyal medya kullanan ve sosyal medyada mikro ünlü takip kişilerden oluşmaktadır. Örneklem metodu olarak tesadüfi olmayan kolayda örnekleme metodu seçilmiştir. Tesadüfi olmayan kolayda örnekleme metodu, tüketici davranışları araştırmalarında daha hızlı, az maliyetli ve temsil gücü yüksek şekilde veri toplayabilmek için faydalıdır (Gegez, 2015). Oluşturulan anketin pilot testi sonrasındaki nihai hali 415 kişiye dağıtılmış ve 390 katılımcıya ulaşılmıştır. Anket geri dönüş oranı \%94'tür. Anket ile katılımcılardan veri toplama işlemi 2018 yılının Aralık ayı ile 2019 yılı Şubat ayları arasında gerçekleştirilmiştir.

\section{Araştırma bulguları}

Tablo 1'de görüldüğü gibi anketi yanttlayan katılımcıların büyük çoğunluğu kadın (\%62.56), 18 ile 24 yaş arasında (\%46.92), Instagram kullanıc1sidır (\%66.41). 
Tablo 1. Anket katılımcılarının demografik özellikleri

\begin{tabular}{lll}
\hline Demografik Özellikler & $\mathbf{N}$ & $\mathbf{\%}$ \\
\hline Cinsiyet & & \\
\hline Kadın & 244 & 62.56 \\
Erkek & 146 & 37.44 \\
\hline Yaş & & \\
\hline $18-24$ & 183 & 46.92 \\
$25-34$ & 176 & 45.13 \\
$35-41$ & 20 & 5.13 \\
42 ve üzeri & 11 & 2.82 \\
\hline Sosyal Medya Platformu & & \\
\hline Twitter & 6 & 1.54 \\
Instagram & 259 & 66.41 \\
Facebook & 7 & 1.79 \\
YouTube & 103 & 26.41 \\
Diğer & 15 & 3.85 \\
\hline
\end{tabular}

Ölçeklerin geçerliliklerini incelemek için, ilk olarak anketi oluşturan ifadeler alanında uzman kişiler tarafından değerlendirilmiştir. Böylelikle, araştırmanın ölçmeyi amaçladığı kavramların belirtilen ölçeklerle ölçülebileceği test edilerek içerik geçerliliği ispatlanmıştır. Ölçeklerin geçerliliklerini inceleme amacıyla yapılan çalışmaları güçlendirmek adına sonrasında yapısal eşitlik modeli ile, AMOS 21 yazılım programı kullanılarak doğrulayıcı faktör analizi yapılmıştır. Doğrulayıcı faktör analizinden faydalanılarak ölçeklerin yakınsama (convergent validity) ve ayrışma geçerlilikleriyle (discriminant validity) ilgili bilgi edinilmiştir. Araştırmada kullanılan ölçekler alanda farklı araştırmacılar tarafından test edilmiş ve kabul görmüş ölçeklerdir. Bu sebeple doğrulayıcı faktör analizinin kullanılması uygun bulunmuştur.

Modelin veriyle uyumunu test etmek için Hair ve arkadaşlarının (2006) önerisi dikkate alınarak Ki-Kare Uyum Istatistiği, Normlaştırılmış Uyum İndeksi (Normed Fit Index-NFI), Karşılaştırmalı Uyum İndeksi (Comparative Fit Index-CFI), Artmalı Uyum İndeksi (Incremental Fit Index-IFI), Uyum İyiliği İndeksi (Goodness of Fit Index-GFI), Tucker-Lewis İndeksi (Tucker-Lewis Index-TLI) incelenmiştir. Tablo 2'de de görülebileceği gibi, $X^{2} / \mathrm{df}, \mathrm{CFI}, \mathrm{IFI}, \mathrm{TLI}, \mathrm{NFI}, \mathrm{GFI}, \mathrm{RMSEA}$ değerleri istenen değerlerde veya bu değerlere oldukça yakındır (Forner ve Larcker, 1981, Hair vd., 2006; Hooper vd., 2008). Bu durumda, ön görülen modelin istenen kavramları 
ölçmek ve araştırma amacına ulaşmak için ideal bir model olduğu söylenebilir.

Doğrulayıcı faktör analizini takiben araştırmada kullanılan ölçeklerin istatistiksel açıdan güvenilirliğini test etmek içsel güvenilirliğin testi yapılmıştır. Bunun için Cronbach alfa katsayıları ve bileşik güvenilirlik katsayıları (composite reliability-CR) hesaplanmıştır. Alanda daha önce yürütülmüş benzer çalışmalarda olduğu gibi, önerilen güvenilirlik katsay1ları incelenerek kullanılan ölçeklerin 'güvenilir' olduğu ispatlanmıştır (Nunally, 1978; Fornell ve Larcker, 1981; Anderson ve Gerbing, 1988).

Araştırmada ele alınan değişkenlerin standart faktör yükleri, Cronbach alfa güvenilirlik katsayıları ve CR değerleri Tablo 2'de sunulmuştur. Cronbach Alfa değerleri 0.772 ile 0.948 arasında; CR değerleri 0.789 ile 0.948 arasındır. Bu değerler tavsiye edilen güvenilirlik değeri olan $0.60^{\prime} \tan$ büyüktür ve bu ölçeklerin güvenilir olduğun göstermektedir (Fornell ve Larcker, 1981). Faktörlere ilişkin açıklanan varyans değerlerinin önerilen değer olan 0.50 'den yüksek olması, ölçeğe ilişkin ifadeler arasında yakınsama geçerliliğinin olduğunu göstermektedir (Bagozzi ve Yi, 1988). Ayrışma geçerliliği ise, ortalama açıklanan varyans (Average Variance Extracted-AVE) değeri ile korelasyon katsayılarının karelerin karşılaştırması ile değerlendirilmiştir. Faktörlere ait AVE değerleri 0.557 ile 0.860 değerleri arasında bulunmaktadır. AVE değerlerin faktörler arası korelasyon katsayılarının karelerinden fazladır ve bu durum tek boyutluluğun göstergesidir, faktörlerin ayrıştığı anlamına gelmektedir (Fornell ve Larcker, 1981). 
Mikro Ünlülerin Tüketicilerin Satın Alma Niyeti Üzerindeki Etkisini İncelemeye Yönelik

Tablo 2. Faktör yükleri, güvenilirlik ve geçerlilik katsayıları ${ }^{3}$

\begin{tabular}{|c|c|c|c|c|}
\hline Değişken & $\begin{array}{l}\text { Standart } \\
\text { Faktör Yükleri }\end{array}$ & $\begin{array}{l}\text { Cronbach } \\
\text { Alfa }\end{array}$ & CR & AVE \\
\hline Kaynak Çekiciliği (SCA) & & .805 & .810 & .589 \\
\hline SCA1 & $.87^{* * * *}$ & & & \\
\hline SCA3 & $.74^{* * * *}$ & & & \\
\hline SCA4 & $.68^{* * * *}$ & & & \\
\hline Kaynak Uzmanlığı (SCE) & & .772 & .825 & .622 \\
\hline SCE1 & $.83^{* * *}$ & & & \\
\hline SCE2 & $.89^{* * *}$ & & & \\
\hline SCE3 & $.53^{* * *}$ & & & \\
\hline Kaynak Güvenilirliği (SCT) & & .820 & .828 & .618 \\
\hline SCT1 & $.70^{* * * *}$ & & & \\
\hline SCT2 & $.86^{* * *}$ & & & \\
\hline SCT4 & $.79^{* * * *}$ & & & \\
\hline Ürün-Ünlü Uyumu (PM) & & .948 & .948 & .860 \\
\hline PM1 & $.89^{* * *}$ & & & \\
\hline PM2 & $.96^{* * *}$ & & & \\
\hline PM3 & $.93^{* * *}$ & & & \\
\hline Tüketici Tutumu (CA) & & .889 & .883 & .655 \\
\hline AT1 & $.89^{* * * *}$ & & & \\
\hline AT2 & $.89^{* * * *}$ & & & \\
\hline AT3 & $.73^{* * *}$ & & & \\
\hline AT5 & $.71^{* * *}$ & & & \\
\hline $\begin{array}{l}\text { Elektronik Ortamda Ağız- } \\
\text { dan Ağıza İletişim (EWOM) }\end{array}$ & & .786 & .789 & .557 \\
\hline EWOM2 & $.80^{* * * *}$ & & & \\
\hline EWOM3 & $.78^{* * *}$ & & & \\
\hline EWOM4 & $.65^{* * *}$ & & & \\
\hline Satın Alma Niyeti (PI) & & .937 & .938 & .834 \\
\hline $\mathrm{PI} 2$ & $.91^{* * *}$ & & & \\
\hline PI3 & $.92^{* * *}$ & & & \\
\hline PI4 & $.91^{* * *}$ & & & \\
\hline
\end{tabular}

Bu verilere ek olarak Tablo 3'de faktörler arası korelasyon katsayıları, tanımlayıcı istatistik ve standart sapma değerleri yer almaktadır. Sunulan değerler uygun aralıkta yer almaktadır.

${ }^{3} \mathrm{Not}: X^{2}=673,91(d f=187), p<.001 ; X^{2} / d f=3.6 ; R M S E A=.08 ; C F I=.92 ; I F I=.92 ; T L I=.9 ; N F I=.89 ; v e$ $G F I=.87,{ }^{* * *} p<.001$. 
Tablo 3. Betimleyici istatistikler ve korelasyon katsayıları

\begin{tabular}{llllllllll}
\hline & Ortalama & $\begin{array}{l}\text { Standart } \\
\text { Sapma }\end{array}$ & $\mathbf{1}$ & $\mathbf{2}$ & $\mathbf{3}$ & $\mathbf{4}$ & $\mathbf{5}$ & $\mathbf{6}$ & $\mathbf{7}$ \\
\hline SCA & 2.706 & 1.010 & 1.00 & & & & & & \\
\hline SCE & 3.853 & 0.817 & $.176^{* *}$ & 1.00 & & & & & \\
\hline SCT & 3.758 & 0.872 & $.459^{* *}$ & $.372^{* *}$ & 1.00 & & & & \\
\hline PM & 3.512 & 1.003 & $.320^{* *}$ & $.144^{* *}$ & $.247^{* *}$ & 1.00 & & & \\
\hline CA & 3.131 & 0.930 & $.416^{* *}$ & $.081^{* *}$ & $.236^{* *}$ & $.521^{* *}$ & 1.00 & & \\
\hline EWOM & 2.670 & 1.024 & $.490^{* *}$ & $.012^{* *}$ & $.239^{* *}$ & $.396^{* *}$ & $.682^{* *}$ & 1.00 & \\
\hline PI & 2.504 & 0.959 & $.312^{* *}$ & $.071^{* *}$ & $.043^{* *}$ & $.336^{* *}$ & $.489^{* *}$ & $.516^{* *}$ & 1.00 \\
\hline
\end{tabular}

${ }^{* *}$ Pearson Korelasyon $p<0.01$.

Ön görülen ilişkilerin testi için, paket programdaki en yüksek olabilirlik hesaplama tekniği kullanılmıştır. Analiz sonucunda elde edilen uyum iyiliği indeksleri model ile veri arasındaki yüksek uyumluluğu göstermektedir. İlgili uyum iyiliği indeksi değerlerinin istenen aralıkta olması model ile veri arasındaki uyumun iyi seviyelerde olduğunu göstermektedir (Nunally, 1978; Fornell ve Larcker, 1981). $X^{2} / \mathrm{df}=3,9, \mathrm{CFI}=0.9, \mathrm{IFI}=$ $0.9, \mathrm{NFI}=0.88, \mathrm{GFI}=0.86$, RMSEA $=0.9$ değerleri belirtilen kritik seviyelerde veya bu kritik seviyelere oldukça yakındır (Nunally, 1978; Fornell ve Larcker, 1981; Anderson ve Gerbing, 1988). Bu durum, veriler ile teorik modelin uyum sağladığının temel kanıtıdır (Fornell ve Larcker, 1981).

Araştırma modelinin test edilerek yapısal modelin açığa çıkarıldığı nihai hali Şekil 2'de sunulmuştur. Şekilde, modelin standart regresyon katsayıları görülebilir. Ek olarak model, tüketici satın alma niyetindeki değişimin \% 35'ini açılamaktadır. Bu bakımdan modelin açıklama gücünün iyi seviyede olduğu savunulabilir. 


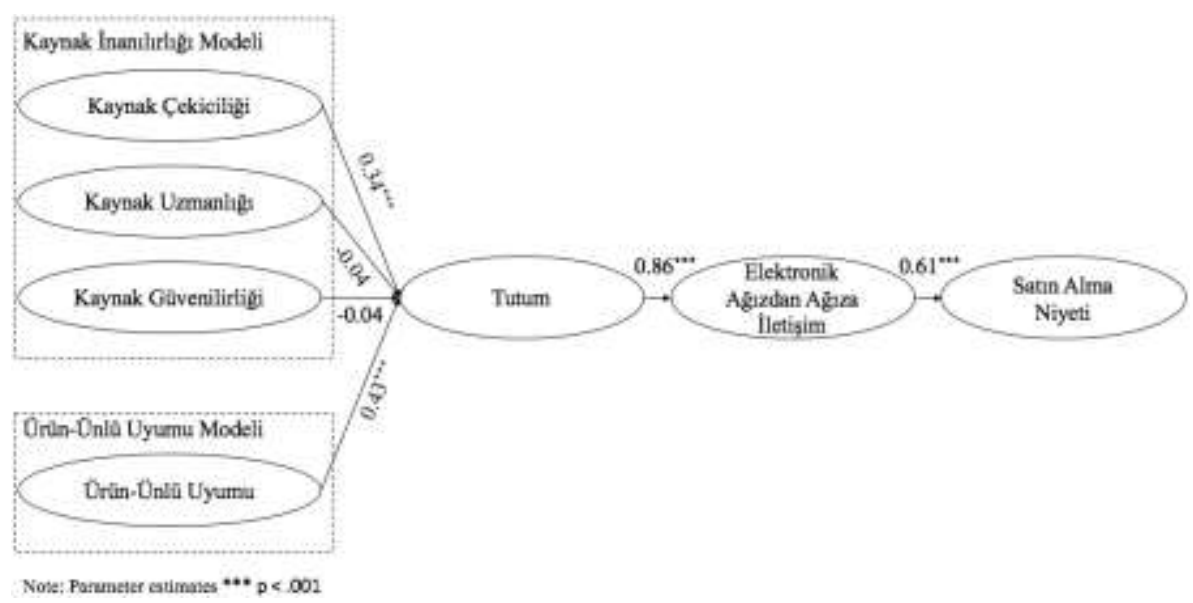

Şekil 2. Yapısal modele ait katsayılar

Çalışmada uyum iyiliğine sahip model için yapılmış olan diğer bir değerlendirme de hipotezlerin test edilmesidir. Yapılan analiz sonucu Tablo 4'de gösterilmektedir.

Tablo 4. Yapısal eşitlik modeli ve hipotezlerine ait değerler

\begin{tabular}{|c|c|c|c|}
\hline Hipotezler & $\begin{array}{l}\text { Standart } \\
\text { Regresyon } \\
\text { Katsay1si }\end{array}$ & $t$ değeri & Sonuçlar \\
\hline H1: SCA $\rightarrow$ CA & 0.34 & $5.89^{* * * *}$ & Desteklendi \\
\hline H2: $\mathrm{SCE} \rightarrow \mathrm{CA}$ & -0.04 & -0.59 & Desteklenmedi \\
\hline H3: SCT $\rightarrow$ CA & -0.04 & -0.56 & Desteklenmedi \\
\hline H4: $\mathrm{PM} \rightarrow \mathrm{CA}$ & 0.43 & $9.93^{* * *}$ & Desteklendi \\
\hline H5: CA $\rightarrow$ EWOM & 0.86 & $15.41^{* * *}$ & Desteklendi \\
\hline H6: EWOM $\rightarrow$ PI & 0.61 & $10.76^{* * *}$ & Desteklendi \\
\hline
\end{tabular}

Tablo 4' de değişkenler arasındaki ilişkilere ait istatistik değerler gösterilmiştir. Hipotez etkileri incelendiğinde, mikro ünlülerin çekiciliği ve tüketici tutumunun istatiksel olaran anlamlı şekilde ilişkili olduğu görülmüştür $(\beta=0.34 ; t=5.89 ; p<0.001)$. Böylelikle, H1 desteklenmiştir. Mikro ünlülerin uzmanlığının tüketici tutumunu pozitif şekilde etkilediğini öngören ikinci hipotez istatistiksel olarak anlamlı verilerle ispatlanamamış- 
tır, desteklenememiştir $(\beta=-0.04 ; t=-0.59 ; p>0.05)$. Mikro ünlülerin güvenilirliği ve tüketici tutumunu inceleyen $\mathrm{H} 3$ hipotezi istatiksel oranlarla desteklenememektedir $(\beta=-0.04 ; t=-0.56 ; p>0.05)$. Yapılan testlerin sonucunda dördüncü hipotezin öngördüğü ürün-ünlü uyumu ve tüketici tutumu arasındaki pozitif ilişki istatistiksel olarak anlamlı bulunmuştur, desteklenmiştir $(\beta=0.043 ; t=9.93 ; p<0.001)$. Tüketici tutumunun elektronik ortamdaki ağızdan ağıza iletişimi pozitif şekilde etkilediğini tahmin eden $\mathrm{H} 5$, elde edilen sonuçlar ile desteklenmiştir $(\beta=0.86 ; t=15.41 ; p<$ 0.001 ). Altıncı hipotez olan ve elektronik ortamdaki ağızdan ağıza iletişim ile tüketici satın alma niyetinin pozitif ilişkili olduğunu savunan H6 elde edilen sonuçlara göre desteklenmiştir $(\beta=0.61 ; t=10.76 ; p<0.001)$.

\section{Tartışma ve sonuç}

Günümüzde, bireyler günlerinin önemli bir zamanını sosyal medyada geçirmektedir. Bu bakımdan mobil yaşayan bireyler için, mobil iletişim kampanyaları yürütmek önem arz etmektedir. Ancak tüketicileri her zaman her yerde yakalayabilmek mesajın doğru ve olumlu algılanacağı anlamına gelmeyebilir. Bu nedenle, onlara daha yakın, onların arasından birilerinin seslenmesi ve pazarlarıma mesajlarını iletmesi önem taşır. Ülkemizde de sosyal medya kullanımı oldukça yaygındır. Benzer şekilde, ülkemizde ünlüler ve mikro ünlülerin sosyal medyadaki popülariteleri incelendiğinde, mikro ünlülerin giderek artan bir kitleye hitap ettiği görülebilmektedir.

Çalışma çerçevesinde incelenen kaynağa ilişkin etkenlerin; mikro ünlü çekiciliği, mikro ünlü uzmanlığı, mikro ünlü güvenilirliği, ürün ile ünlü uyumu, tüketici tutumu; tüketici tutumunun elektronik ortamda ağızdan ağıza iletişim ve elektronik ortamda ağızdan ağıza iletişimin satın alma niyeti üzerinde etkili olup olmadığı bulunmak istenmiştir. Böylelikle, bilhassa pazarlama iletişimi çalışmaları olmak üzere tüketici davranışları için yeni bir dönemin temsilcisi olan tüketicilerin ünlenerek birer kaynak haline gelmesi konusuna yönelik ampirik bulgular sunulmaktadır.

Tüketicinin bir kaynakta dikkat edeceği ilk şey olan görünümün, kaynak çekiciliğinin, çalışma sonucunda tüketicilerin tutumu üzerinde etkili olduğu saptanmıştır. Buna sebep olabilecek faktörlerin başında kullanıc1ların satın almayı tercih edecekleri ürünlerin fiziki veya dış görünüş ile 
ilgili bir ürün olabileceği gelebilir. Dış görünüşü ilgilendiren bir ürün satın alımı yapılacağı sırada, o ürünü tüketiciye tanıtacak mikro ünlünün de çekiciliğinin ön planda olması muhtemeldir. Anket verileri incelendiğinde, bu durum katılımciların kullandıkları platformlardan resim ve video paylaşım sitesi olan Instagram ve YouTube'un ilk iki sırada yer alması ile ilişkilendirilebilir. Günümüzde birçok güzellik uzmanı, moda ikonları, moda tasarımcıları ve spor eğitmenlerinin Instagram ve YouTube platformlarını aktif olarak kullanmaları, sürekli olarak takipçileri ile iletişim halinde olmaları bu iddiayı güçlendirir niteliktedir. Kaynak çekiciliğinin tüketici tutumu ile pozitif ilişkili bulunması geçmiş çalışmalarda rastlanan sonuçlar ile de desteklenir niteliktedir (Mawrick, 2015; Lee ve Watkins, 2016; Djafarova ve Trofimenko, 2019).

Kaynak inanılırlığı modelinin bir diğer etkeni olan kaynak uzmanlığı, kaynak çekiciliğinin aksine tüketici tutumu ile ilişkili bulunmamıştır. Tüketicilerin bir ürün veya hizmet alırken yapacaklarından biri de işin uzmanına danışmaktır. Tüketicilerin bu yaklaşımı, sosyal medya üzerinden etkileşimde bulundukları mikro ünlüler konusunda geçerli görünmemektedir. Mikro ünlülerin geleneksel ünlüler gibi tüketici toplumun çoğunluğuna kendilerini henüz kabul ettirmiş olamamaları bir neden olarak gösterilebilir. Mikro ünlüler geleneksel ünlüler gibi toplumun geneli tarafından tanınmamakta ve bilinmemektedir. Mikro ünlülerin etkisi genellikle takipçi sayısı, beğeni ve yapılan yorumlar üzerinden ölçülmektedir (Utz, 2010). Bu durum da bir muğlaklığı beraberinde getirmektedir. Her tüketicinin uzmanlık algısı farklı olabilir. Örneğin, kimi için yüz bin takipçi yeterli bir uzmanlık derecesi olarak algılarken, kimileri için bu değer beş yüz bin olabilir. Kaynak uzmanlığının tüketici tutumu ile ilişkili çıkmamasına sebep olabilecek bir başka etken de tüketicilerin mikro ünlüleri kendileri gibi görmeleri ve onları da birer tüketici olarak algılamaları olabilir. Hwang ve Zhang (2018) yaptıkları çalışmada mikro ünlüler ile takipçilerin bir ünlü hayran ilişkisinden çok bir arkadaş ilişkisine sahip olduklarını belirtmiştir. Eğer tüketiciler takip ettikleri mikro ünlüleri kendilerine birer arkadaş olarak görüyorlarsa bu da onları tüketicilerin gözünde bir uzman sıfatı kazanmalarını zorlaştırabilir.

Araştırma sonuçlarında kaynak güvenilirliği de kaynak uzmanlığı gibi tüketici tutumu ile ilişkili bulunmamıştır. Geçmiş çalışmalarda (Djafarova ve Rushworth, 2017; Hwang ve Zwang, 2018; Djafarova ve Trofimenko, 
2019), mikro ünlülerin çıkış noktasının tüketici temelli olduğu, sosyal medya üzerinden yayınladıkları paylaşımlarda kar amacı gütmedikleri, bu nedenle de mikro ünlü güvenilirliği ile tüketici tutumu arasında bir ilişkiye rastlandığını aktarılmıştır. Bu çalışmada herhangi bir etkiye rastlanmamasının nedeni, ülkemizde mikro ünlülerin yaptıkları çalışmaların tüketici temelli değil, reklam ve parasal güdümlü gerçekleştirildiği algıs1nın bulunması olabilir. Mikro ünlüler yaptıkları reklam içerikli paylaşımlar için belirli bir ücret almaktadırlar ve ünlülerin sosyal medyada yaptıkları paylaşım başına ücret aldıkları tüketiciler tarafından bilinen bir detaydır. Ancak sosyal medya kullanımının artması, mikro ünlülerin yaygınlaşması gibi gelişmeler neticesinde işletmelerin reklam çalışmalarına bu alanlarda ağırlık vermesi ile tüketicilerin bu tür mesajlara maruz kalma sıklı̆̆ı artmıştır. Böylelikle, bu tür mesajların bireysel bir deneyim aktarmaktan ziyade direkt para karşılığı yapılan mekanik paylaşımlar olarak algılanıyor olması olağandır. Sürekli olarak farklı marka ve ürünlere ait paylaşım yapılması, paylaşım sayılarının fazlalığı, marka çeşitliliği tüketicilerde güven oluşturmayabilir. Bu algı mikro ünlünün artık tüketici için bir ürünü denediği, onu test ettiği imajına zarar verebilir. Tüketici mikro ünlünün artık tüketici odaklı değil kâr odaklı, maddi boyutları düşünerek paylaşım yaptı̆̆ fikrine kapılabilecektir. Mevcut çalışmada da herhangi bir platform veya kategori ayrımı gözetmeksizin bir araştırma yürütüldüğünden, bu sık maruz kalma durumunun tüketici zihninde açığa çıkmış olabileceği, tüketici bu sıklığı hatırlamış olabileceği çıkarımı yapılabilir.

Araştırma bulgularına göre, ürün ile ünlü uyumu tüketici tutumu üzerinde pozitif bir etkiye sahiptir. Bu bulgu, geçmiş çalışmaları destekler niteliktedir (Kamins ve Gupta 1994; Biswas vd., 2006; Lee ve Thorson, 2008). Tüketiciler bir ürün alırken ürünü tanıtan ünlü kişi ile pazarlaması yapılan ürünün veya hizmetin birbiri ile uyum içerisinde olmasına dikkat eder. Örnek olarak bir şefin sosyal medya hesabı üzerinden yaptığ1 paylaşımlarını takip eden bir tüketiciyi ele alalım. Şefin kendi alanı dışından bir paylaşım yapması, takipçisinin tutumunu -onu takip etme sebebinin dışında bir alanla karı karşıya kaldığından- değiştirebilir. Araştırma sonuçları da bu durumu desteklemektedir. Sosyal medya ünlülerinin paylaşımları incelendiğinde hepsinin bir fikir ya da alan seçimine dayandığı fark edilmektedir. Bu da paylaşımları ile kendileri arasında bir harmoninin olduğunu gösterir. 
Araştırmanın bir diğer desteklenen hipotezi tüketici tutumunun elektronik ortamda ağızdan ağıza iletişimi pozitif şekilde etkilediği şeklindedir. Sosyal medya üzerinden mikro ünlü ile etkileşimde bulunan tüketicilerin bu etkileşim sonrasında sosyal medya aracilığı ile akran ve arkadaşlarıyla iletişime geçtiği görülmüştür. Bu iletişimin en büyük sebepleri arasında, insanların sürekli olarak sosyal medya kullanması ve sosyal çevreleri ile bu mecralar yoluyla iletişim kurması gösterilebilir. Çünkü sosyal medya platformlarının tasarım şekli bu tarz aktiviteleri destekleyecek ve teşvik edecek şekilde geliştirilmiştir. Bir tüketicinin sosyal medyada beğendiği bir ürünü, hemen arkadaşlarıyla paylaşmak istemesi ve bunu sadece birkaç saniye içinde hiç yorulmadan birkaç tuşla yapabilmesi elektronik ortamda ağızdan ağıza iletişimi daha cazip hale getirmektedir. Sadece kullanım kolaylığı değil aynı zamanda birden fazla kullanıc ile aynı anda iletişime geçilmesi de elektronik ortamda ağızdan ağıza iletişimi tüketicilere daha cazip hale getiren etkenlerden biridir. Benzer bir şekilde Djafarova ve Rushworth (2017), Hwang ve Zhang (2018), Djafarova ve Trofimenko (2019) tüketicilerin kendilerine yakın buldukları mikro ünlüleri, sosyal medya platformlarında arkadaşlarına ve çevrelerine önerdiklerini, onların yapmış oldukları paylaşımları kendi hesaplarında paylaşarak duyurduklarını belirtmişlerdir.

Çalışmanın son hipotezi olan elektronik ortamda ağızdan ağıza iletişimin satın alma niyeti üzerindeki pozitif etkisi istatistiksel olarak desteklenmiştir. Tüketiciler bir ürün veya hizmet almadan önce ilk olarak o ürünü daha önceden almış olan tanıdıkları kişilere başvuracaklardır (Pitta ve Fowler, 2005). Çünkü tüketiciler için en güvenilir kaynak önceliği her zaman sosyal çevrelerinde yer alan bireyler olmuştur (Chan ve Ngai, 2011). Bu bulgu, yapılan bir çok çalışmayı destekler niteliktedir (Chan ve Ngai, 2011; Jin ve Phua, 2014; Erkan ve Evans, 2016). Mikro ünlülerin tüketicilerin satın alma niyetleri üzerindeki etkisini araştıran bu araştırma da göstermektedir ki tüketiciler, sosyal medya platformları aracılığıyla kendi aralarında yapmış oldukları iletişim ile birbirlerinin satın alma niyetlerini etkileyebilmektedir. 


\section{Uygulamaya yönelik öneriler}

$\mathrm{Bu}$ araştırma işletmelerin tüketicilere ulaşmasında ve onları etkileyerek satış amaçlı hedeflere ulaşmasında yardımcı olacak yeni nesil bir iletişim kaynağı olan mikro ünlülere odaklanmaktadır. Çalışma sonucu ortaya çıkan ve pozitif bir şekilde desteklenen bulgulara bakıldığında; bunlar işletmeler için, pazarlama çalışmalarına yön verecek birer veri olarak kabul edilebilir. Bu verilerden ilki mikro ünlülerin kaynak olarak seçilirken öncelikli olarak dikkat edilmesi gereken hususun, kaynak olarak çekici özelliklere sahip olmaları gerektiğidir. Fiziksel, sosyal vb. bir yönden çekici mikro ünlülerin tüketicilerin tutumu üzerinde olumlu bir etkiye sahip olduğu gözlemlenmiştir. Buradaki çekicilik kavramı değişkenlik gösterebilir. Bu değişkenliğin sebebi markaların ürünlerine uygun düşecek, ürünü görsel açıdan destekleyebilecek bir özelliğin bulunmasıdır. Örneğin, eğer bir makyaj markası tanıtımı için mikro ünlü ile anlaşılacak ise o mikro ünlünün yüz güzelliği ön planda olan, takipçileri tarafından beğenilen, güzelliğini kanıtlamış bir mikro ünlü olması gerekir. Spor kıyafetleri pazarlayan bir marka reklamında oynayacak mikro ünlü seçimi yapılacağı zaman ise, sportif kıyafetleri öne çıkaracak fiziksel çekiciliğe sahip bir mikro ünlü seçilebilir.

İşletmelerin başarılı bir mikro ünlü seçimi yapmak için dikkat etmesi gereken ikinci özellik mikro ünlülerin tanıtımı yapılacak ürün ile uyum sağlayabilmesidir. Bir mikro ünlünün çekiciliği her zaman için tek başına yeterli olmayabilir. Bu bakımdan markaların mikro ünlüleri dikkatli bir şekilde analiz etmesi önemlidir. Bu analiz hem ürün için hem de mikro ünlü için paralel bir şekilde yürütülür. Ürünün bulunduğu sektör, sağladığı fayda, hitap ettiği kesim, tüketicilere sağladığ1 kolaylıklar vb. değişkenlerin mikro ünlü tarafından ne şekilde gösterilebileceği, mikro ünlünün de ürün gibi tüketicilerin gözündeki yeri, hitap ettiği tüketici grubu, o ürünün sadece reklamını yapmayıp aynı zamanda kendisinin de kullanacağını ikna edebileceği bir birey olması gerekmektedir.

\section{Araştırma kısıtları ve gelecek çalışmalar için öneriler}

Yapılan çalışma bazı kısıtlamalar dâhilinde gerçekleştirilmiştir. Çalışmanın karşılaştığı ilk kısıt ülkemizin iki şehrinde yapılmasıdır. Tüketicilerin 
satın alma niyetlerinin ülkenin belirli bir bölgesinde yer alan belli bir grup üzerinden değerlendirilmesi sonuçların genellenebilirliği için kısıt teşkil eder. Gelecek araştırmalarda, tüm ülkeyi kapsayacak geniş bir çalışmanın yürütülmesi fayda sağlayabilir.

Ek olarak bu çalışmada, tüketicilere uygulanan anketlerde herhangi bir özelleştirme yapılmamış; cinsiyet, yaş, eğitim düzeyi, gelir durumu ve kullanılan platformlar ayrıştırılmamıştır. Gelecek çalışmalarda daha detaylı incelemeler yapılarak çeşitli karşılaştırmalı analizler sunabilir. Örneğin, farklı yaş gruplarında, farklı eğitim seviyelerinde, farklı gelir seviyelerinde mikro ünlülerin etkileri araştırılabilir. Bu karşılaştırmalar, ülkemizde mikro ünlülerin birer kaynak olarak kabulüne ilişkin çeşitli kümeleri gösterebilir. Gelecek çalışmalarda kaynağın yanı sıra paylaştıkları bilgilerin içeriği ve bilgi paylaşma şekilleri de analiz edilebilir. Böylelikle kaynağa ilişkin veriler derinleştirilebilir. Örneğin, bilginin görselle mi, yazıyla mı, videoyla mı paylaşıldığı veya bilginin uzunluğu, içerdiği detayların farklı etkilere yol açıp açmadığı analiz edilebilir. Böylelikle, hem akademi hem sektör için faydalı sonuçlar sunulabilir. 


\title{
EXTENDED ABSTRACT
}

\section{An Empirical Study about the Effect of Micro-Celebrities on Consumers' Purchase Intention}

\author{
* \\ Ebru Tümer Kabadayı - Alev Koçak Alan - Nilşah Cavdar Aksoy - \\ Salih Can Sidar \\ Gebze Technical University
}

The advantage of spreading the ideas emerging through the influence of social media to the broad masses is the indicator of the new role of consumers in social media. The definitions of this new role have different meanings for users who use different platforms. The holistic term that can be used for social media users, who became a celebrity through the dissemination of the shares they made, is 'Micro Celebrity' (Khamis, 2017).

Micro celebrities increased their popularity over time, and positioned themselves as a new means of promotion in the eyes of the brands. There are limited studies about micro celebrities from marketing and consumer behavior perspectives (Chung and Cho, 2017; Djafarova and Rushworth, 2017; Lim et al., 2017; Hwang and Zhang, 2018; Djafarova and Trofimenko, 2019) and most of these studies do not provide empirical evidence. In our country, there is no empirical study on micro celebrities with this perspective. In this study, a research was carried out on the extent to which micro celebrities affect consumers' decisions. The aim of the study is to examine the effects of the promotions that micro celebrities who entered people's lives and become an important source of communication all over the world, and have an increasing importance in Turkey, made on the purchase intention of individuals.

The Source Credibility Model (Hovland et al., 1953; Ohanian, 1990; Ohanian, 1991) and the Product Matchup Model (Forkan, 1980) provide theoretical support to enable individuals to shape their purchasing behav- 
iors by creating an effective message as a result of a correct source selection. In this context, the source attractiveness, source expertise, source trustworthiness, and product matchup which may reveal attitude, then electronic mouth to mouth, and finally purchase intention represent the focal points of the study.

- H1: Micro celebrity's attractiveness has a positive effect on consumer attitude.

- H2: Micro celebrity's expertise has a positive impact on consumer attitudes.

- H3: Micro celebrity's trustworthiness has a positive effect on consumer attitude.

- H4: Product matchup with the micro celebrity has a positive effect on consumer attitude.

- H5: Consumer attitude has a positive effect on eWOM.

- H6: eWOM has a positive effect on purchase intention.

In this study, data were collected online via survey method. The survey consisted of demographic questions, and the items adapted from multiitem scales. After a pilot test with 30 respondents, the survey reached 390 people though non-probability convenience sampling method.

Most of the respondents were male, aged between 18-24, are using Instagram.

For the validity and reliability of the scales, the questionnaire was read by the expert academicians in the field of consumer behavior. Then, convergent validity and discriminant validity of the scales were obtained by using confirmatory factor analysis. After that, the reliability of the scales was also tested. The compatibility of the model with the data was also investigated through fit indices (Hair et al., 2006).

Factor loadings, Cronbach alpha coefficients, composite reliability scores, AVE values, and fit indices are found in the desired range. Thus, the validity and reliability of the scales are proved.

Correlation coefficients, descriptive statistics and standard deviation values also in the desired range. The measurement model has also significant fit indices. In addition, the model explains 35\% of the variability in purchase intention. When it comes to hypothesis testing, 3 of 5 hypotheses are supported. 
The positive relationship between source attractiveness and consumer attitude is supported by the results of previous studies (Mawrick, 2015; Lee and Watkins, 2016; Djafarova and Trofimenko, 2019). Source expertise was not associated with consumer attitudes. The fact that micro celebrities haven't yet adopted the majority of the society in Turkey like traditional celebrities. Besides, the effect of micro celebrities is generally measured by the number of followers, likes and comments (Utz, 2010), bringing an ambiguity. Besides, consumers can see micro celebrities as themselves and perceive them as consumers rather than an expert. In parallel, the source trustworthiness wasn't positively related to consumer attitude. The reason for this can be the perception that the activities of micro celebrities in our country is not based on experiences, but rather on advertising and money driven.

The harmony between the product and the celebrity has a positive effect on consumer attitude, providing evidence to the past studies (Kamins and Gupta 1994; Biswas et al., 2006; Lee and Thorson, 2008). Besides, the consumer attitude positively affects eWOM. It was seen that the consumers who interacted with micro celebrities through social media communicated with people in their social network. The positive effect of eWOM on purchase intention was also supported statistically. This finding supports many past studies (Chan and Ngai, 2011; Jin and Phua, 2014; Erkan and Evans, 2016).

The study provides some managerial implications based on the research findings. First, a micro celebrity to be chosen as the source should be attractive. The micro celebrity found attractive in the context of the related campaign will have the power to change the attitudes of individuals in the desired direction, in a positive way. Second, selected micro celebrities should be harmonizing with the related product. Some cases in the past have shown that the beauty of celebrities is not enough to affect the consumer.

When it comes to limitations of this research, the first limitation is that only two cities represented the country within this study. In future research, conducting a broad study covering the whole country may be beneficial. Besides, a holistic approach was used in this study, including the 
respondents from all ages, genders, education levels etc. In future research, comparative studies can be conducted based on different demographics. In addition, the ways of sharing the information can also be analyzed.

\section{Kaynakça / References}

Anderson J. C. ve Gerbing, D. W. (1988). Structural equation modeling in practice: A review and recommended two-step approach. Psychological Bulletin, 103(3), 411-423.

Arli, D. (2017). Does Social media matter? investigating the effect of social media features on consumer attitudes media features on consumer attitudes. Journal of Promotion Management, 23(4), 521-539.

Audi, M. ve Ghazzawi, K. (2015). The effect of celebrity endorsement on creating brand loyalty: An application on the lebanese cosmetic sector's demand. International Journal of Business Management and Economic Research, 6(5), 273-287.

Bagozzi, R. P., and Yi, Y. (1988). On the evaluation of structural equation models. Journal of the Academy of Marketing Science, 16(1), 74-94.

Biswas, D. A. ve Biswas, D. N. (2006). The differential effects of celebrity and expert endorsements on consumer risk perceptions. The role of consumer knowledge, perceived congruency, and product. Journal of Advertising, 35(2), 17-31.

Boerman, S. C., Willemsen, L. M. ve Van Der Aa, E. P. (2017). "This post is sponsored" effects of sponsorship disclosure on persuasion knowledge and electronic word of mouth in the context of facebook. Journal of Interactive Marketing, 38, 82-92.

Brison, N. T., Byon, K. K. ve Baker, T. A. (2016). To tweet or not to tweet: The effects of social media endorsements on unfamiliar sport brands and athlete endorsers. Innovation, 18(3), 1-18.

Chan, Y. Y. Y. ve Ngai, E. W. T. (2011). Conceptualising electronic word of mouth activity: an input-process-output perspective. Marketing Intelligence \& Planning, 29(5), 488-516.

Choi, S. M. ve Rifon, N. J. (1990). It is a match: The impact of congruence between celebrity image and consumer ideal self on endorsement effectiveness. Psychology \& Marketing, 29(9),639-650. 
Chung, S. ve Cho, H. (2017). Fostering parasocial relationships with celebrities on social media: Implications for celebrity endorsement. Psychology \& Marketing, 34(4), 481-495.

Ding, Y. ve Qiu, L. (2017). The impact of celebrity-following activities on endorsement effectiveness on microblogging platforms: A parasocial interaction perspective. Nankai Business Review International, 8(2), 158-173.

Djafarova, E. ve Rushworth, C. (2017). Exploring the credibility of online celebrities' Instagram profiles in influencing the purchase decisions of young female users. Computers in Human Behavior, 68, 1-7.

Djafarova, E. ve Trofimenko, O. (2019). 'Instafamous'-credibility and selfpresentation of micro-celebrities on social media. Information, Communication \& Society, 22(10), 1432-1446.

Erdogan, B. Z. (1999). Celebrity endorsement: A literature review. Journal of Marketing Management, 15(4), 291-314.

Erkan, I. ve Evans, C. (2016). The influence of eWOM in social media on consumers' purchase intentions: An extended approach to information adoption. Computers in Human Behavior, 61, 47-55.

Forkan, J. (1980). Product matchup key to effective star presentations. Advertising Age, 51, 42-58.

Fornell, C. ve Larcker, D. F. (1981). Evaluating structural equation models with unobservable variables and measurement error. Journal of Marketing Research, 18(1), 39-50.

Gegez, A. E. (2015). Pazarlama araştırmaları. İstanbul: Beta Basım Yayım Dağtım A.S,

Goldsmith, R. E., Lafferty, B. A. ve Newell, S. J. (2000). The impact of corporate credibility and celebrity credibility on consumer reaction to advertisements. Journal of Advertising, 29(3), 43-54.

Gong, W. ve Li, X. (2017). Engaging fans on microblog: the synthetic influence of parasocial interaction and source characteristics on celebrity endorsement. Psychology \& Marketing, 34(7), 720-732.

Hair, J. F., Black, W. C., Babin, B. J. ve Anderson, R. E. (2010). Multivariate Data Analysis: A Global Perspective. New Jersey: Pearson Education. 
Harrison, W. L. (2001). The measurement of word-of-mouth communication and an investigation of service quality and customer commitment as potential antecedents. Journal of Service Research, 4(1), 6075.

Hassan, S. R. U. ve Jamil, R. A. (2014). Influence of Celebrity Endorsement on Consumer Purchase Intention for Existing Products: A Comparative Study. Journal of Management Info, 4(1), 1-23.

Hooper, D., Coughlan, J. ve Mullen, M. (2008). Structural equation modelling: Guidelines for determining model fit. Library Articles, Dublin Institue of Technology.

Hovland, C. I., Janis, I. L. ve Kelley, H. H. (1953). Communication and persuasion. New Haven, CT, US: Yale University Press.

Hwang, K. ve Zhang, Q. (2018). Computers in human behavior Influence of parasocial relationship between digital celebrities and their followers on followers' purchase and electronic word-of-mouth intentions, and persuasion knowledge. Computers in Human Behavior, $87,155-173$.

Jin, S. A. A. ve Phua, J. (2014). Following celebrities' tweets about brands: The impact of twitter-based electronic word-of-mouth on consumers' source credibility perception, buying intention, and social identification with celebrities. Journal of Advertising, 43(2), 181-195.

Kahle, L. R. ve Homer, P. M. (1985). Physical attractiveness of the celebrity endorser: A social adaptation perspective. Journal of Consumer Research, 11(4), 954-961.

Kamins, M. (1990). An investigation into the "match-up" hypothesis in celebrity advertising: When beauty may be only skin deep. Journal of Advertising, 19(1), 4-13.

Kamins, M. ve Gupta, K. (1994). Congruence between spokesperson and product type: A matchup hypothesis perspective. Psychology $\mathcal{E}$ Marketing, 1(1), 569-586.

Khamis, S., Ang, L. ve Welling, R. (2017). Self-branding,'micro-celebrity'and the rise of Social Media Influencers. Celebrity Studies, 8(2), 191-208.

Kim, H., Ko, E. ve Kim, J. (2015). SNS users' para-social relationships with celebrities: social media effects on purchase intentions. Journal of Global Scholars of Marketing Science, 25(3), 279-294. 
Kim, Y. J. ve Na, J. H. (2007). Effects of celebrity athlete endorsement on attitude towards the product: the role of credibility, attractiveness and the concept of congruence. International Journal of Sports Marketing and Sponsorship, 8(4), 23-33.

Lee, J. G. ve Thorson, E. (2008). The impact of celebrity-product incongruence on the effectiveness of product endorsement. Journal of Advertising Research, 48(3), 433-449.

Lee, J. E. ve Watkins, B. (2016). YouTube vloggers' influence on consumer luxury brand perceptions and intentions. Journal of Business Research, 69(12), 5753-5760.

Lim, X. J., Cheah, J. H. ve Wong, M. W. (2017). The impact of social media influencers on purchase intention and the mediation effect of customer attitude. Asian Journal of Business Research, 7(2), 19.

Marwick, A. E. (2015). Instafame: Luxury selfies in the attention economy. Public Culture, 27(1 (75)), 137-160.

McCormick, K. (2016). Celebrity endorsements: Influence of a product-endorser match on Millennials attitudes and purchase intentions. Journal of Retailing and Consumer Services, 32, 39-45.

McGinnies, E. ve Ward, C.D. (1980). Better liked than right: Trustworthiness and expertise as factors in credibility. Personality and Social Psychology Bulletin, 6(3), 467-472.

McGuire, W. J. (1985). Attitudes and attitude change. The Handbook of Social Psychology, 233-346.

Metzger, M. J., Flanagin, A. J., Eyal, K., Lemus, D. R. ve McCann, R. M. (2003). Credibility for the 21st century: Integrating perspectives on source, message, and media credibility in the contemporary media environment. Annals of the International Communication Association, Communication Yearbook, 27(1), 293-335.

Miller, G. R. ve Baseheart J. (1969). Source Trustworthiness, Opinionated Statements, and Response to Persuasive Communication. Speech Monographs, 36(1), 1-7.

Nunnally, J. C. and Bernstein, I. H. (1967) Psychometric theory. New York: McGraw-Hill.

Ohanian. R. (1990). Construction and Validation of a Scale to Measure Celebrity Endorser's Perceived Expertise, Trustworthiness, and Attractiveness. Journal of Advertising, 19(3), 39-52. 
Ohanian. R. (1991). The impact of celebrity spokespersons' perceived image on consumers' intention to purchase. Journal of Advertising Research, 31(1), 46-54.

Qin, Y. (2017). Research on the Influence of Social Media Information on Consumers' Purchase Intention. MATEC Web of Conferences, 139, 00109.

Pitta, D. A. ve Fowler, D. (2005). Online consumer communities and their value to new product developers. Journal of Product \& Brand Management, 14(5), 283-291.

Rifon, N. J., Jiang, M. ve Kim, S. (2016). Don't hate me because I am beautiful: Identifying the relative influence of celebrity attractiveness and character traits on credibility. Advances in Advertising Research, 6(1), 125-134.

Senft, T. M. (2013). Microcelebrity and the branded self. A Companion to New Media Dynamics, 346-354.

Teng, L., Laroche, M. ve Zhu, H. (2007). The effects of multiple-ads and multiple-brands on consumer attitude and purchase behavior. Journal of Consumer Marketing, 24(1), 27-35.

Till, B. D. ve Busler, M. (1998). Matching Products with Endorsers: Attractiveness versus Expertise. Journal of Consumer Marketing, 15(6), 576-84.

Till, B. D. ve Busler, M. (2000). The Match-up Hypothesis: Physical Attractiveness, Expertise, and the Role of Fit on Brand Attitude, Purchase Intent and Brand Beliefs. Journal of Advertising, 39(3), 1-13.

Um, N. H. (2016). Predictors of the effectiveness of celebrity endorsement on Facebook. Social Behavior and Personality: an International Journal, 44(11), 1839-1850.

Um, N. H. (2018). What affects the effectiveness of celebrity endorsement? Impact of interplay among congruence, identification, and attribution. Journal of Marketing Communications, 24(7), 746-759.

Utz, S. (2010). Show me your friends and I will tell you what type of person you are: How one's profile, number of friends, and type of friends influence impression formation on social network sites. Journal of Computer-Mediated Communication, 15(2), 314-335. 
Wang, S. W., Kao, G. H. ve Ngamsiriudom, W. (2017). Consumers' attitude of endorser credibility, brand and intention with respect to celebrity endorsement of the airline sector. Journal of Air Transport Management, 60, 10-17.

We Are Social ve Hootsuite. (2019). Digital 2019 Turkey. Accessed on 15th of May 2019 from https://www.slideshare.net/DataReportal/digital-2019-turkey-january-2019-v01

Wright, S. A. (2016). Reinvestigating the endorser by product matchup hypothesis in advertising. Journal of Advertising, 45(1), 26-32.

Yeon Kim, H. ve Chung, J. E. (2011). Consumer purchase intention for organic personal care products. Journal of Consumer Marketing, 28(1), 40-47.

\section{Kaynakça Bilgisi / Citation Information}

Kabaday1-Tümer, E., Koçak-Alan, A., Cavdar-Aksoy, N. ve Sidar, C.S. (2019). Mikro ünlülerin tüketicilerin satın alma niyeti üzerindeki etkisini incelemeye yönelik ampirik bir çalışma. OPUSUluslararası Toplum Araştırmaları Dergisi , 12(18. UİK Özel Sayısı), 230-261. DOI: 10.26466/opus.583856 